In January, 1926, further experiments with definite standardised models of the apparatus were made at the large logging operations at Lidingö. The result of these experiments can be summed up as follows:

After several trials a standard model of the apparatus was decided upon-well-balanced in its details, strong and very serviceable and giving complete satis faction. The only part which requires, after a reasonable time, to be renewed is the spring, but this is to be expected and is easily done. On account of its light weight, the apparatus can be carried by the cutter without inconvenience; and it is very simple and easy to set up for work.

For cutting down trees, especially of average or large size, it is most useful, as well for increasing efficiency in sawing as for making the work easier for the men. In Fig. 4 are recorded some of the curves showiug the working results for the Garpenberg experiments, in connection with the saws of Type XII $\mathrm{N}$ and 25 .

The XII N saw is a common single saw of a 1924 model, which has been used with and without the new apparatus. The horizontal lines give the area and diameter of the sawed trees, and the vertical linies the time it took to saw the respective trunks.

On account of forced sawing during this experiment, the results show as higher than normal. It is noticeable, kowever, that the same saw used with the apparatus shows about double the sawing effect than when used in the ordinary way for which this saw is intended, on account of the regulating influence of the spiral spring on the blade, and the consequent better steering, saw$\log$ through a diameter of twelve inches.
In addition to this must be counted the greater fect which it is possible to obtain with the use of a t] ner and longer sawblade (entailing less friction : a larger cutting area); everyone will therefore is ize that considerable work is saved and better resi obtained with a special blade.

In Figure 5 are given sawing times for differ dimensions, and a number of special blades, as used the last experiments at Lidingö, where all the saw was done with the "Kompisapparat."

It is to be noted that these times, unlike the figr in Figure 4, were obtained by steady, regular work d by experienced woodworkers, and thus can be regar as normal results for log sawing in a temperature ( or 5 degrees (Réaumur) - about $40^{\circ} \mathrm{F}$.

As a comparison, saw No. 25 was used in both th experiments. Saw No. 23 in Figure 5 is the one alre described, which is accepted as the standard model this apparatus.

For sawing felled trees, the saving in effort by ing the apparatus is not so striking, but, particul for average anid large sizes, the trouble of placing apparatus is highly rewarded. Therefore, even if advantage is slight in comparison with that in usin for standing trees, the apparatus is well worth whj

From these extensive experiments and observati it may be concluded that the apparatus is an impor invention which should be popular with wood work It can now be obtained from the factory, address $\mathrm{S} \varepsilon$ vikens Jernverks A.-B., Sandviken, Sweden. The p of the apparatus with the special saw is approxima $\$ 5.60$, an extra saw without handle is $\$ 1.15$, and extra spring $50 \mathrm{c}$.

\title{
Impressions of the World's Forestry Conference
}

The World's Forestry Conference, held at Rome, April 29 to May 5, 1926, was described by C. S. Dana, of the American Forestry Association and head of the American delegation to the conference, as "The greatest gathering of foresters that has ever met." Delegates came from more than 50 countries, speaking many different languages; yes, even thinking in entirely different ways - their thoughts influenced largely by the development and economic conditions of the community from which they had come. Thus, the forester from southern Europe includes in his forest estimates all material, even to branchwood and twigs, and these are sold for fagots or for other uses, returning a considerable revenue; the northern foresters include stem and bark, but not branchwood; the American only that portion of stem that can be manufactured to a four-inch top in the East or to a 12 to 14-inch top on the Pacific Coast.

It is only after the most careful study of the vast amount of material included in the proceedings, covering 3500 pages, that one dare draw any definite conclusions from the work accomplished there. It seems, however, that the most important step taken at the conference was the recommendation for the establishment of a bureau for collecting and disseminating w forest statistics. The importance of this work is further emphasized by visiting the many forest a of Europe, viewing their choice bits of forest, and ing told that this or that area contains 700 or 800 bic meters per hectare, which, after calculating for duction in bark and branchwood, is equivalent to 000 board feet per acre. We had seen many sin acres in the Rocky Mountain region cruised at 15 to 20,000 board feet. Even traveling for a few mor stopping a day or two here and a day there, does give one sufficient data to form definite conclusi Impressions are formed however, and it is these sonal impressions that I give in reply to your inq regarding forest conditions in Europe.

\section{The Timber Supply of Europe}

Since the war the European cut is increasing will during the next few decades furnish more material than ever before. In southern Europe many years prior to the war the eut was regulater a very conservative basis. If the growth was esti ed at 10 cubic meters per hectare, the cut was rest ed to nine, the balance going to increase the $\mathrm{fc}$ capital. Now, due to many causes, the process 
een reversed, and the cut is often 10 to 20 per cent reater than the estimated growth. It would appear lat this process of gradual reduction of forest capital iight continue for some years.

In northern Europe one is surprised that countries ke Finland and Sweden can continue to produce, ear and year out, such large quantities of timber.

Finland will probably be the greatest factor in the uropean timber situation, or the greatest factor exspt Russia, at present an unknown quantity. That a Juntry of only $95,000,000$ acres, situated north of the th parallel and to a large extent within the Aretic ircle, can export two billion feet of sawn material, in lead the world in the export of veneers and bobins, and can produce large and increasing quantities : pulp and pulp products, is little short of a marvel. Then one learns that within the century fires were unning unrestrained over southern Finland, and that 3 per cent of her forest area has grown up since, the Sarvel grows. After meeting and discussing the quesfon of forest eulture with those responsible for the rrest polioy in Finland, and after seeing the careful oudies they have made in reproduction, growth and mesent stand, you are convinced that the production permanent. The growth is estimated at 44.4 milDn cubic meters, the eut at 40.0 million. Further, Onland has no coal, and large quantities of wood are fsed for power and fuel purposes-2,000,000 cords on ne state railways. One pulp company advised they oed 400,000 cubic meters of fuel wood as compared ofth 320,000 cubic meters of pulpwood. Finland has es reserves for water power, estimated at $2,500,000$ Pिsepower. This is now being actively developed, of, when this development is completed, will release of the wood now used for power purposes for 造her development of wood industries.

Eweden largely duplicates what has been said about Silland and will continue to be a very important timDroducer. Great Britain and Holland are both Titending their forest areas through extensive planting :ograms. These areas in 15 to 20 years will begin to roduce mine props and other small-sized timber, hich forms a very large percentage of the timber conmed in Guropo.
My impression, then, is that for the present generation there will be little, if any, actual shortage in the timber supply, but the next generation may have to depend largely on Russia and tropical woods. The supply for the succeeding generations, especially in America, will depend very largely on our actions now, and how successful we are in controlling the forest fire problem. Finland is a glowing example of what can be accomplished in this respect. Further, the first pinch of forest famine will be want of large-sized material, such as we are now cutting with so much extravagance that it scarcely returns the cost of manufacturing.

\section{Silviculture in Europe}

Silviculture in Europe is still largely experimental, and many of the theories of a quarter of a century ago are being discarded. If there is one common thought running through forest practice it is "Get back as close to nature as possible." In no place is this more apparent than in the elaborately regulated forests of Saxony. Here, instead of the homogeneous stands regulated into even-age classes so much sought after, they are now working to secure heterogeneous stands, both in age classes and species. These stands help to preserve the fertility of the soil and are more resistant to windfall and attacks of insects-damage much feared by all European foresters. Planting is being placed in a secondary position and used to fill in gaps and to extend forest areas, rather than the main source of the forest crop.

While the European forester still has to face many of the problems which confront us in the West, he has this tremendous advantage - a ready market for all the product he ean grow and cheap labor to remove and manufacture it. Almost all operations in the woods are conducted by the forest owner. The basis of the operation is not, as with us, the greatest profit from logging, but an improvement in forest investment. It is the remaining stand with which the operator is chiefly concerned; the product of his logging is secondary.-The Timberman. 


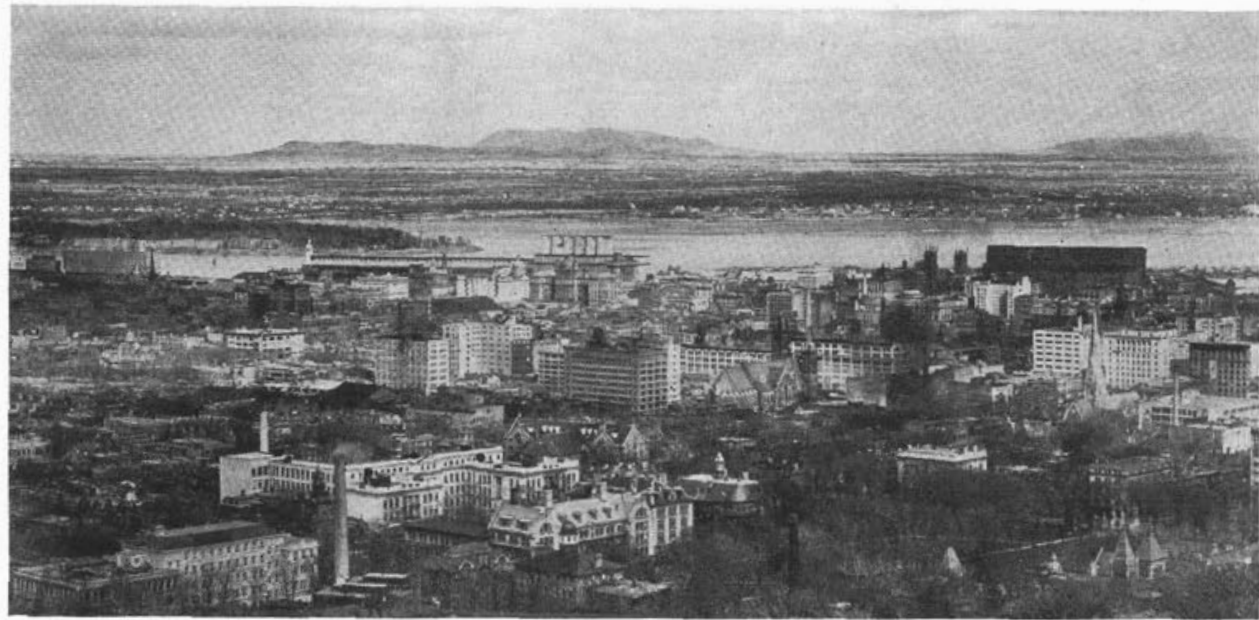

$\mathrm{M}-\mathrm{O}-\mathrm{N}-\mathrm{T}-\mathrm{R}-\mathrm{E}-\mathrm{A}-\mathrm{L}$.

Montreal mey be considered the metropolis of Canada;

the largest city of the country, the busiest, and, with Quebec, the most venerable in associations of the past. Superlatives are unavoidable when vriting of liontreal. In addition to the qualities ennumerated she is essentially cosmopolitan, and with this goes gaiety. She is the gay city, the Paris of Canada. Lcross the border these facts are abundantly roalized, $S$ is show by one constant invasion of Americans, thirsty and pleasure-seeking.

For two notable days in this month of January ( $25 \mathrm{th}$ and $26 \mathrm{th}$ ) it will be possible for foresters from all over the Dominion to satisfy themselves that there is no exaggeration in these words. Those among them who already know Montreal will be able to renew their acquaintance under the happiest auspices. Those who do not, have in store all the delights of a first visit. Membors of both groups, converging upon the mountain city, will have a rare chance 
of meeting kindred spirits, and of discussing the problems of their profession. For these two days are to be forestry days. Three bodies, each of them of the utmost interest to all foresters, have chosen these days for their annual meetings. These are the Canadian Society of Forest Fngineers, the Woodland Section of the Pulp and Paper Association, and the $\mathrm{C}_{\mathrm{a}}$ nadian Forestry Association. Come to Montreal and help us sing - "Tle won't be home "til morning!"

\section{Schedule of Events.}

The Canadian Forestry Association will hold a morning and afternoon session in the rinds or Hotel on Tuesday, January 25th. A comprehensive programme has been arranged dealing largely with forest fire protection vork. is public luncheon will be held at which special speakers will be featured.

In the evening the Society vill hold its annual dinner at the Jindsor, tickets $\$ 1.50$. This will be a real get-to-gether. Following the dinner will be the annual business meeting when it is hoped most of the business for the past year will be got through and definite plans made for the future. Plan to stay for this and say s omething!

On Wednesday, the 26th, the whole day vill be given to technical papers, the programme of which is as follows:- 
Forest lianagement.

$$
\begin{aligned}
& \text { Paper by H.G. Mright. } \\
& \text { Paper by Ellwood Wilson. } \\
& \text { Paper by H.M. Robertson. }
\end{aligned}
$$

Progress in Aerial sketching of Forest ireas.

$$
\text { Paper by F.T. Jenkins. }
$$

The Development of a Forest Nursery and Its Problem.

$$
\text { Paper by F.S. Newman. }
$$

New Methods in Forest Fire Protection.

Paper by C.H. Morse.

Unfinished business.

The following day, Thursday, the 27th, the Foodland Section of the Pulp and Paper issociation vill hold its annual meeting as a part of the Pulp and Paper issosiation, in the Ritz Carlton Hotel.

The result of the recent election of officers is as

follows:-

$$
\begin{aligned}
& \text { President. B.F. Avery• } \\
& \text { Vice President. P.Z. Caverhill. } \\
& \text { Secretary• A.H. Richardson. } \\
& \text { Treasurer. Clyde Leavitt. }
\end{aligned}
$$

District Executives.

Quebec and Haritime Provinces.

L.S. $7 e b b_{2}$ Ellwood Hilson, W.G. Wright.

Ontario.

$$
\begin{aligned}
& \text { R.D. Craig, } \\
& \text { E.J. Zavitz, } \\
& \text { J.H. Mite. }
\end{aligned}
$$


Prairie Provinces.

C. Lia cFayden,

D.i. liacDonald,

C.H. liorse.

British Columbia.

L.R. indrews,

H.R. Christie,

P.L. Ly ford. 